\title{
PENGARUH FAKTOR RISIKO TERHADAP EKSPRESI RESEPTOR ESTROGEN PADA PENDERITA KANKER PAYUDARA DI KOTA PADANG
}

\author{
Suci Estetika Sari ${ }^{1}$,Wirsma Arif Harahap ${ }^{2}$, Deddy Saputra ${ }^{3}$
}

\begin{abstract}
Abstrak
Kejadian kanker payudara menduduki peringkat kedua tertinggi yang diderita oleh wanita di Indonesia. Kejadian kanker payudara dipengaruhi beberapa faktor risiko. Estrogen reseptor merupakan marker biologi pada pemeriksaan imunohistokimia dan dapat memberikan prognosis dan jenis terapi terhadap kanker payudara. Tujuan penelitian ini adalah menentukan pengaruh faktor risiko terhadap ekspresi reseptor estrogen pada penderita kanker payudara. Studi ini menggunakan metode analitik observasional dengan desain cross sectional. Penelitian ini menggunakan data sekunder pada Registrasi Bagian Bedah Divisi Bedah Onkologi RS Dr. M. Djamil Padang dan Registrasi Kanker Payudara PERABOI Cabang Padang. Hasil analisis multivariat didapatkan tiga faktor risiko yang memiliki pengaruh terhadap ekspresi reseptor estrogen adalah: status menopause dengan $p=0,04$; paritas dengan $p=0,01$ dan indeks massa tubuh dengan $p=0,08$. Simpulan penelitian ini adalah faktor risiko yang memiliki pengaruh terhadap ekspresi reseptor estrogen yaitu status menopause, paritas dan indeks massa tubuh.
\end{abstract}

Kata kunci: kanker payudara, faktor risiko, ekspresi reseptor estrogen

\section{Abstract}

The case of breast cancer is the second rank among the woman in Indonesia. Breast cancer is influenced by several risk factor. Estrogen reseptor is one of biological markers from immunohistochemical analysis and can provide prognosis and kind of therapies for breast cancer. The objective of this study was to determine the influence of risk factor on estrogen reseptor expression in breast cancer patient in Padang. This research used cross sectional design. This study used secondary data from RS DR. M. Djamil Oncolgy Division registration data and registration of PERABOI Padang. The result of this research showed the three risk factors influence on reseptor estrogen expression were; menopause state with $p$ value 0,04; parity with $p$ value 0,01 and body mass index with $p$ value 0,08 . Conclusion of thi study is three risk factors influence on estrogen reseptor expression are menopause state, parity, and BMI.

Keywords: breast cancer, risk factor, estrogen reseptor

Affiliasi penulis: 1. Prodi Kedokteran Fakultas Kedokteran Universitas Andalas Padang (FK Unand), 2. Bagian Bedah Onkologi FK Unand, 3. Bagian Bedah Plastik FK Unand

Korespondensi: Suci Estetika Sari, Email: suciestetika@gmail.com,Telp: 085760347714

\section{PENDAHULUAN}

Kanker payudara adalah suatu pertumbuhan abnormal sel kelenjar, saluran kelenjar dan jaringan penunjang payudara yang tumbuh infiltratif dan dekstrutif, serta dapat bermetastasis. ${ }^{1}$
Ditinjau dari biomolekuler, kanker payudara merupakan penyakit akibat mutasi gen yang dipicu oleh multifaktor seperti faktor diet, faktor lingkungan, dan faktor keturunan yang dikenal sebagai faktor risiko. Faktor risiko yang erat kaitannya dengan peningkatan insiden kanker payudara antara lain jenis kelamin wanita, usia > 50 tahun, riwayat keluarga dan genetik (Pembawa mutasi gen BRCA1, BRCA2, ATM atau TP53 (p53)), riwayat penyakit payudara sebelumnya (DCIS pada payudara yang sama, LCIS, 
densitas tinggi pada mamografi), menarche dini $(<12$ tahun) atau menstruasi lambat (>55 tahun), riwayat reproduksi (tidak memiliki anak dan tidak menyusui), hormonal, obesitas, konsumsi alkohol, riwayat radiasi dinding dada dan faktor lingkungan. ${ }^{1}$

Kanker payudara merupakan salah satu masalah kesehatan yang penting di dunia. Kanker payudara merupakan keganasan yang paling sering ditemukan pada wanita di seluruh dunia. Menurut data Globocan tahun 2012 diketahui bahwa terdapat 1,67 juta kasus baru yang terdiagnosis pada tahun 2012 atau sekitar $25 \%$ dari seluruh kanker. Kanker payudara lebih sering terjadi pada negara berkembang dibandingkan negara maju. Angka kejadian untuk daerah Afrika dan Asia yaitu sebesar 27/100.000 penduduk. $^{2}$

Kanker payudara menempati urutan kedua setelah kanker serviks di Indonesia. Secara nasional prevalensi penyakit kanker pada penduduk Indonesia tahun 2013 sebesar 1,4 per 1000 penduduk atau diperkirakan sekitar 374.792 orang dan prevalensi kanker payudara pada wanita Indonesia adalah sebesar 50 per 100.000 penduduk. Prevalensi kanker di Sumatera Barat tahun 2013 sebesar 1,7 per 1000 penduduk dan Sumatera Barat merupakan Provinsi ketiga dari 34 Provinsi tertinggi kejadian kanker payudara dengan prevalensi sebesar 90 per 100.000 penduduk. ${ }^{1}$

Di Rumah Sakit Umum Pusat (RSUP) Dr. M. Djamil padang yang merupakan rujukan nasional, kanker payudara merupakan jenis kanker yang paling banyak ditemukan dari seluruh kanker. Data Rekam Medik RSUP DR. M. Djamil Padang pada Irna Bedah tahun 2013, tercatat 160 kasus kanker payudara, mengalami penurunan pada tahun 2014 yaitu 139 kasus dan pada tahun 2015 kanker payudara mengalami peningkatan kembali yaitu 174 kasus. ${ }^{3}$

Berdasarkan American Cancer Society, didapatkan rerata harapan hidup pasien kanker payudara stadium III adalah sebesar $84 \%$, sedangkan stadium IV hanya sebesar $19 \%$. Data National Cancer Database pada tahun 2001-2002, didapatkan harapan hidup 5 tahun pasien kanker payudara stadium IIIA sebesar $67 \%$, IIIB sebesar $41 \%$, IIIC sebesar $39 \%$, serta stadium IV sebesar $15 \%{ }^{4}$
Wanita memiliki resiko yang lebih tinggi untuk terkena kanker payudara dibandingkan laki-laki, dikarenakan wanita lebih terpajan terhadap hormon estrogen. Kanker payudara kebanyakan terjadi pada wanita usia setengah baya dan lansia. Seperti karsinoma yang lain, risiko kanker payudara meningkat seiring bertambahnya usia. $^{5}$ Kanker payudara jarang terjadi pada wanita berusia kurang dari 30 tahun kecuali pada beberapa kasus yang berhubungan dengan dengan faktor familial. ${ }^{6}$ Risiko akan terus meningkat tajam sampai dengan usia 4045 tahun, lalu akan cenderung menetap setelah menopause. $^{7}$

Faktor hormonal termasuk salah satu faktor risiko penting terhadap kejadian kanker payudara. Peningkatan eksposur terhadap hormon estrogen akan meningkatkan risiko terjadinya kanker payudara, sedangkan mengurangi eksposur ini dapat meproteksi terjadinya kanker payudara. Faktor lain adalah: usia menarche, status menopause, usia melahirkan anak pertama, jumlah paritas, menyusui, penggunaan kontrasepsi oral dan terapi hormon pengganti. ${ }^{\left({ }^{(8)}\right.}$

Beberapa penelitian yang telah pernah dilakukan membuktikan pengaruh faktor hormonal terhadap kejadian kanker payudara. Penelitian Indrati tahun salah satu rumah sakit di Semarang menunjukkan peningkatan resiko kanker payudara pada usia menarche kurang dari 12 tahun $^{9}$ Penelitian lain juga menunjukkan hubungan yang cukup berarti antara kanker payudara dengan siklus menstruasi yang pendek. Status menopause juga menunjukan pengaruh yang cukup berarti pada kejadian kanker payudara. Wanita post menopause memiliki risiko 4,18 kali lebih tinggi untuk terkena kanker payudara. ${ }^{10}$

Beberapa faktor lain yang juga berperan dalam terjadinya kanker payudara yaitu faktor genetik, gaya hidup serta lingkungan. ${ }^{8}$ Beberapa penelitian menunjukkan bahwa pola diet makanan berlemak dengan frekuensi yang tinggi dapat meningkatkan risiko terkena kanker payudara. ${ }^{(9)}$

Penderita kanker payudara dengan usia muda memiliki prognosis yang lebih buruk dari penderita dengan usia yang lebih tua yang memiliki harapan hidup yang lebih baik. Hal ini menunjukkan banyak faktor yang dapat mempengaruhi prognosis pada 
penderita kanker payudara. Faktor yang menentukan atau berhubungan dengan perjalanan alami penyakit tanpa pemberian terapi sistemik dan dapat menggambarkan agresifitas penyakit kanker secara utuh disebut dengan faktor prognostik. ${ }^{11}$

Pada pemeriksaan imunohistokimia dapat diketahui nilai beberapa reseptor kanker payudara yaitu: estrogen, progesteron dan protein HER2/neu. ${ }^{12}$ Reseptor-reseptor ini dapat digunakan sebagai biomarker untuk prognostik dan prediktif spesifik pada pasien dengan kanker payudara. ${ }^{13}$ Reseptor estrogen merupakan salah satu faktor prognosis dan faktor prediktif utama yang diperiksa pada kanker payudara. Reseptor estrogen diekspresikan secara berlebihan pada sekitar $70 \%$ dari kanker payudara yang dikenal sebagai Estrogen Receptor Positive (ER positif). Status reseptor estrogen digunakan untuk menentukan sensitifitas lesi kanker payudara terhadap terapi anti estrogen dan untuk menilai sensitifitas kemoterapi preventif pada wanita yang memiliki risiko tinggi kanker payudara. ${ }^{14}$

Karsinoma dengan salah satu hormon reseptor positif secara biologis dan klinis menunjukan risiko mortalitas lebih tinggi dibandingkan karsinoma dengan kedua hormon reseptor positif. Sekitar 2/3 wanita penderita kanker payudara berumur $<50$ tahun memiliki ER positif, sementara sekitar $80 \%$ tumor pada wanita berusia $>50$ tahun memiliki ER positif. ${ }^{13}$

Berdasarkan pemaparan diatas, diketahui faktor risiko memiliki pengaruh yang cukup besar terhadap kejadian kanker payudara. Oleh karena itu peneliti tertarik untuk melakukan penelitian mengetahui pengaruh faktor risiko kanker payudara terhadap prognostik pada kanker payudara yang dilihat melalui ekspresi resptor estrogen pada hasil pemeriksaan imunohistokimia terhadap penderita kanker payudara di Kota Padang.

\section{METODE}

Penelitian ini merupakan studi analitik observasional dengan design penelitian cross sectional. Penelitian ini dilakukan pada data sekunder pada Registrasi bagian Bedah Divisi Bedah Onkologi RS DR. M. Djamil Padang dan Registrasi Kanker Payudara PERABOI Cabang Padang.
Populasi penelitian ini adalah semua data penderita kanker payudara di Kota Padang. Sampel penelitian adalah bagian dari populasi yang memenuhi kriteria inklusi dan tidak termasuk kriteria eksklusi. Teknik pengambilan sampel yang digunakan yaitu consecutive sampling, yaitu semua sampel yang ada dan memenuhi kriteria akan dimasukkan sebagai sampel hingga jumlah sampel minimal yang dibutuhkan terpenuhi. Kriteria inklusi yaitu penderita kanker payudara di Kota Padang yang ditegakkan dengan hasil uji klinis dan uji histopatologi penderita kanker payudara di Kota Padang dengan kelengkapan data yang dibutuhkan. Kriteria eksklusi ialah penderita laki-laki kanker payudara di Kota Padang, penderita kanker payudara disertai kanker pada organ lainnya yang bukan metastasis kanker payudara.

Variabel yang diteliti dalam penelitian ini terbagi atas variabel terikat dan variabel bebas. Variabel terikat adalah reseptor estrogen, sedangkan variabel bebas yaitu usia, riwayat kanker payudara dalam keluarga, usia menarche, status menopause, usia saat melahirkan anak pertama, paritas, penggunaan pil KB, riwayat menyusui, aktifitas fisik, indeks massa tubuh.

Analisis bivariat dilakukan terhadap dua variabel yang diduga memiliki hubungan atau korelasi. Analis ini dilakukan dengan uji Chi-square untuk mengetahui hubungan antara variabel independen dan dependen. Hasil analisis dianggap bermakna bila didapatkan $p<0,1$. Analisis multivariat dilakukan untuk menentukan variabel bebas yang paling dominan hubungannya terhadap variabel terikat. Untuk mengetahui kuatnya hubungan tersebut menggunakan analisis regresi logistik. Analisis multivariat dilakukan dengan dua tahap yaitu pemilihan variabel kandidat dan penentuan variabel model. Hasil analisis dianggap bermakna bila didapatkan $p<0,1$.

\section{HASIL}

\section{IANALISIS BIVARIAT}

Analisis bivariat dilakukan untuk mengetahui besar pengaruh masing-masing faktor risiko terhadap ekspresi reseptor estrogen pada penderita kanker payudara di Kota Padang. Analisis bivariat dilakukan dengan menggunakan uji Chi-square $\left(X^{2}\right)$ untuk mengetahui pengaruh setiap variabel bebas dengan 
variabel terikat. Hasil analisis dianggap bermakna bila nilai $p<0,1$. Berikut hasil analisis bivariat ekspresi ER terhadap masing-masing variabel bebas.

Tabel 1. Pengaruh faktor risiko terhadap ekspresi reseptor estrogen

\begin{tabular}{llc}
\hline No & Variabel & $\mathbf{p}$ \\
\hline 1 & Usia & 0,10 \\
2 & Riwayat KPD keluarga & 0,16 \\
3 & Usia menarche & 0,17 \\
4 & Status menopause & 0,05 \\
5 & Usia MAP & 0,63 \\
6 & Paritas & 0,01 \\
7 & Riwayat menyusui & 0,05 \\
8 & Pil KB & 0,35 \\
9 & Aktifitas fisik & 0,20 \\
10 & Indeks massa tubuh & 0,06 \\
\hline
\end{tabular}

Usia pasien di kategorikan menjadi dua yaitu < 40 tahun dan $\geq 40$ tahun. Berdasarkan hasil analisis uji silang umur pasien pada penelitian ini didapatkan nilai signifikansi sebesar 0,1 yang berarti tidak terdapat perbedaan yang cukup signifikan antara usia terhadap ekspresi reseptor estrogen pada penderita kanker payudara di Kota Padang.

Analisis riwayat kanker payudara pada keluarga dikategorikan menjadi dua yaitu kelompok yang memiliki riwayat KPD keluarga dan tidak memiliki riwayat KPD pada keluarga. Hasil uji statistik tidak didapatkan perbedaan yang signifikan antara riwayat kanker payudara pada keluarga terhadap ekspresi reseptor estrogen pada penderita kanker payudara di Kota Padang.

Analisis terhadap variabel usia menarche dikategorikan menjadi dua yaitu usia menarche $\geq 12$ tahun dan $<12$ tahun. Berdasarkan analisis uji silang didapatkan nilai $\mathrm{p}$ sebesar 0,17 . Hal ini menunjukan bahwa tidak terdapat perbedaan yang signifikan antara usia menarche terhadap ekspresi reseptor estrogen pada penderita kanker payudara.

Pada penelitian ini status menopause dikategorikan menjadi dua yaitu post-menopause dan pre-menopause. Hasil analisis menunjukan nilai signifikansi sebesar 0,05. Hal ini berarti terdapat perbedaan yang signifikan antara status menopause terhadap ekspresi reseptor estrogen pada penderita kanker payudara di Kota Padang. Hasil ini juga mendapatkan bahwa penderita dengan status postmenopause cenderung memiiki ekspresi reseptor estrogen positif sehingga prognosis pada penderita dengan status post-menopause lebih baik dibandingkan dengan penderita pre-menopause.

Pada penelitian ini usia saat melahirkan anak pertama dikategorikan menjadi dua yaitu kelompok usia $<35$ tahun dan $\geq 35$ tahun. Dari hasil uji silang didapatkan nilai signifikansi sebesar 0,63. Hal ini menunjukan bahwa tidak terdapat perbedaan yang signifikan antara usia saat melahirkan anak pertama terhadap ekspresi reseptor estrogen pada pendderita kanker payudara di Kota Padang.

Hasil uji silang pengaruh paritas terhadap ekspresi reseptor estrogen didapatkan nilai $p$ sebesar 0,01 . Hal ini menunjukkan bahwa terdapat perbedaan yang signifikan antara paritas terhadap ekspresi reseptor estrogen pada pendderita kanker payudara di Kota Padang.

Hasil analisis pengaruh riwayat menyusui terhadap ekspresi reseptor estrogen di dapatkan nilai p sebesar 0,05. Hal ini menunjukkan bahwa terdapat perbedaan yang signifikan antara riwat menyusui terhadap reseptor estrogen pada penderita kanker payaudara di Kota Padang. Hasil analisis ini juga menunjukkan bahwa penderita yang memiiki riwayat menyusui anak cenderung memiliki reseptor estrogen positif sehingga memiliki prognosis yang lebih baik.

Penggunaan pil KB dikategorikan menjadi dua yaitu kelompok yang tidak menggunakan pil KB dan kelompok yang menggunakan pil KB. Dari hasil uji silang didapatkan nilai sebesar 0,35 yang menunjukan tidak terdapat perbedaan yang signifikan antara penggunaan pil KB terhadap ekspresi reseptor estrogen pada penderita kanker payudara di Kota Padang.

Aktifitas fisik dikategorikan menjadi dua yaitu kelompok dengan aktifitas fisik $\geq 4$ jam/ minggu dan kelompok dengan aktifitas fisik $<4$ jam/minggu. Dari hasil uji silang didapatkan niai signifikansi sebesar 0,20 yang menunjukkan tidak terdapat perbedaan yang signifikan antara aktifitas fisik terhadap ekspresi reseptor estrogen pada penderita kanker payudara di Kota Padang. 
Indeks Massa Tubuh (IMT) dikategorikan menjadi dua yaitu kelompok dengan IMT $<30 \mathrm{~kg} / \mathrm{m}^{2}$ dan kelompok dengan IMT $\geq 30 \mathrm{~kg} / \mathrm{m}^{2}$. Dari hasil uji statistic didapatkan nilai $p$ sebesar 0,06 . Hal ini menunjukkan terdapat pengaruh yang signifikan antara Indeks Massa Tubuh terhadap ekspresi reseptor estrogen pada penderita kanker payudara di Kota Padang dimana penderita kanker payudara dengan status obesitas (IMT $\geq 30 \mathrm{~kg} / \mathrm{m}^{2}$ ) cenderung memiliki estrogen reseptor negative sehingga memiliki prognosis yang lebih buruk.

\section{IANALISIS MULTIVARIAT}

Tabel 2. Pemodelan multivariat akhir

\begin{tabular}{lccccc}
\hline \multirow{2}{*}{ Variabel } & \multirow{2}{*}{ B } & $\mathbf{p}$ & OR & \multicolumn{2}{c}{\begin{tabular}{c} 
EXP(B) C.I.for \\
\cline { 5 - 6 }
\end{tabular}} \\
\cline { 5 - 6 } & & & & Iower & upper \\
\hline menopause & 0,398 & 0.044 & 2.882 & 1.171 & 7.104 \\
Paritas & 0.906 & 0.013 & 3.875 & 0.226 & 0.724 \\
IMT & 0.573 & 0.085 & 0.566 & 0.342 & 0.931 \\
\hline
\end{tabular}

Hasil analisis secara multivariat ini menunjukkan dari sembilan variabel kandidat yang dianalisis secara bersama-sama, terdapat 3 variabel yang terbukti memiliki pengaruh yang signifikan terhadap ekspresi reseptor estrogen yaitu paritas merupakan varibel yang paling dominan mempengaruhi ekspresi estrogen dengan $p=0,01$, status menopause dengan $p=0,04$ dan indeks massa tubuh dengan $\mathrm{p}=0,08$.

Variabel yang dikeluarkan dari persamaan $(p>0,1)$ yaitu usia, riwayat KPD keluarga, usia menarche, riwayat menyusui, pil KB dan aktifitas fisik.

\section{PEMBAHASAN}

Estrogen Reseptor (ER) merupakan marker biologi yang paling penting pada kanker payudara. Struktur ER pada pasien kanker payudara dapat menjadi respon prediktif terhadap terapi hormonal. Ekspresi protein ER meningkatkan prognosis terhadap penyakit kanker payudara. ${ }^{13}$ Tumor dengan ER negatif memperlihatkan proliferasi dan pertumbuhan tumor lebih agresif demikian juga angka kekambuhan tinggi.

Hasil analisis multivariat dengan regresi logistik metode enter diperoleh 3 variabel yang memiliki pengaruh terhadap ekspresi reseptor estrogen yaitu satus menopause, paritas dan indeks massa tubuh.

\section{Status Menopause}

Pada penelitian ini didapatkan bahwa pasien dengan status post-menopause lebih banyak dibandingkan pasien pre-menopause. Penelitian Indrati menunjukkan bahwa penderita dengan status post-menopause ditemukan lebih banyak dibandingkan penderita kanker payudara dengan status pre-menopause, dan didapatkan wanita postmenopause memiliki risiko 2,25 lebih besar untuk terkena kanker payudara dibandingkan wanita premenopause. $^{9}$

Status menopause menunjukkan perbedaan yang signifikan terhadap ekspresi reseptor estrogen berdasarkan hasil analisis multivariat dengan nilai $p$ sebesar 0,04. Hasil ini juga mendapatkan bahwa penderita dengan status post-menopause cenderung memiiki ekspresi reseptor estrogen positif sehingga prognosis pada penderita dengan status postmenopause lebih baik dibandingkan dengan penderita pre-menopause. Hasil ini sejalan dengan studi oleh Payne et al menunjukkan bahwa lebih dari $80 \%$ wanita post-menopause memiliki reseptor estrogen positif. ${ }^{15}$ Hal ini juga disebutkan pada penelitian Suparman yang menjelaskan tingginya kadar estrogen pada wanita post-menopause dikarenakan tingginya uptake dari hormon dalam sirkulasi. ${ }^{16}$

\section{Paritas}

Pengaruh yang signifikan antara paritas terhadap ekspresi reseptor estrogen dengan $p=0,01$. Hasil observasi menunjukkan persentase pasien yang memiiki anak memiliki ekspresi estrogen positif $(87,7 \%)$ lebih tinggi dibandingan dengan pasien yang tidak memiliki anak. Hal ini menunjukkan pasien yang memiliki anak cenderung memiliki prognosis yang lebih baik dibandingkan dengan penderita yang tidak memiliki anak.

Sebuah studi menunjukkan bahwa wanita nullipara memiliki risiko terkena kanker lebih tinggi, jumlah kehamilan yang lebih tinggi dapat mengurangi risiko terjadinya kanker. Hal ini mungkin disebabkan karena aktivitas hormon progesterone selama masa 
kehamilan dapat membantu terjadinya pematangan sel-sel payudara sehingga mengurangi risiko terjadinya kanker payudara. ${ }^{17-19}$

\section{Indeks Massa Tubuh}

Hasil penelitian selanjutnya menunjukkan pengaruh yang signifikan antara Indeks Massa tubuh dengan ekspresi reseptor estrogen dengan nilai $p$ sebesar 0,06 dimana penderita kanker payudara dengan status obesitas (IMT $\geq 30 \mathrm{~kg} / \mathrm{m}^{2}$ ) cenderung memiliki estrogen reseptor negative sehingga memiliki prognosis yang lebih buruk.

Sebuah studi menjelaskan bahwa obesitas meningkatkan risiko kanker payudara. Pada wanita yang mengalami obesitas akibat pola diet makanan berlemak dengan frekuensi tinggi dapat meningkatkan konsentrasi estrogen dalam darah yang akan meningkatkan risiko terkena kanker payudara karena efek proliferasi dari estrogen pada duktus epitelium payudara. ${ }^{20}$ Beberapa bukti menunjukkan perubahan metabolik pada pasien kanker payudara dengan Body Mass Index (BMI) tinggi. BMI berhubungan dengan resistansi insulin dan khususnya perubahan terkait produksi sitokin oleh jaringan adiposa. Jaringan tersebut merupakan kontributor utama terhadap sifat agresif dari kanker payudara yang berkembang melalui pengaruhnya terhadap angiogenesis dan stimulasi kemampuan invasif dari sel kanker. ${ }^{21}$

\section{Faktor Risiko yang Tidak Terbukti Berpengaruh terhadap Ekspresi Reseptor estrogen}

Analisis yang dilakukan antara variabel penelitian menunjukan beberapa variabel yang diteliti ada yang secara mandiri menunjukan pengaruh yang bermakna terhadap ekspresi reseptor estrogen namun ada juga menunjukkan variabel yang tidak berpengaruh terhadap ekspresi reseptor estrogen. Variabel yang secara mandiri (analisis bivariat) tidak memiliki kemaknaan perbedaan terhadap ekspresi reseptor estrogen adalah usia dengan $p=0,1$; riwayat KPD pada keluarga dengan $p=0,16$; usia menarche dengan $\mathrm{p}=0,17$; penggunaan pil $K B$ dengan $\mathrm{p}=0,1$; dan aktifitas fisik dengan $p$ sebesar 0,2.

Pada penelitian ini usia tidak memiiki perbedaan yang signifikan terhadap ekspresi reseptor estrogen berdasakan hasil analisis multivariat dengan p sebesar 0,1. Namun hasil observasi secara klinis menunjukkan pasien dengan usia $\geq 40$ tahun cenderung memiliki ekspresi estrogen positif lebih tinggi dibandingkan dengan usia $<40$ tahun. Secara kuantitatif dikatakan bahwa kadar ER meningkat dengan meningkatnya usia. Hal ini dapat disebabkan semakin tua usia (dengan perkiraan usia menarche yang tidak variatif) maka paparan estrogen yang dialami akan semakin banyak.

Penelitian oleh Putri menunjukkan bahwa usia dengan kriteria di atas 40 tahun dan 40 tahun ke bawah tidak memiliki perbedaan dengan status reseptor estrogen. Hal yang sama ditunjukkan pada observasi klinis memperlihatan kecenderungan prevalensi reseptor estrogen positif yang lebih tinggi pada wanita penderita kanker payudara usia lebih dan atau sama dengan 40 tahun. $^{13}$

Pasien dengan usia menarche $<12$ tahun $(6.4 \%)$ lebih sedikit dibandingkan dengan pasien usia menarche $\geq 12$ tahun (93.6\%), sementara pada pasien dengan usia menarche $\geq 12$ tahun menunjukkan eskpresi reseptor estrogen positif lebih tinggi (95,3\%) dibandingkan dengan pasien usia menarche $<12$ tahun (4,7\%). Berdasarkan analisis uji silang didapatkan nilai $\mathrm{p}$ sebesar 0,17 yang menunjukkan bahwa tidak terdapat perbedaan yang signifikan antara usia menarche terhadap ekspresi reseptor estrogen pada penderita kanker payudara di Kota Padang.

Dari total 451 data didapatkan pasien yang menggunakan pil KB (9.1\%) lebih sedikit dibandingkan dengan pasien yang tidak menggunakan pil KB (90.9\%). Pasien yang tidak menggunakan pil KB dengan ekspresi reseptor estrogen positif sebanyak 247 orang, lebih tinggi dibandingkan pasien yang menggunakan pil KB dengan estrogen positif. Dari hasil uji silang didapatkan $\mathrm{p}$ sebesar 0,35 yang menunjukan tidak terdapat perbedaan yang signifikan antara penggunaan pil KB terhadap ekspresi reseptor estrogen pada penderita kanker payudara.

Penelitian Yanti menunjukkan terdapat hubungan pemakaian pil $K B$ dengan kejadian kanker payudara dengan nilai OR sebesar 3,6 yang berarti wanita yang memakai pil $K B$ memiliki risiko sebesar 
3,6 kali lebih besar terkena kanker payudara dibandingkan dengan wanita yang tidak memakai pil $\mathrm{KB}^{3}$

Beberapa variabel bebas yang secara mandiri memiliki pengaruh terhadap ekspresi reseptor estrogen namun setelah dilakukan analisis secara multivariat tidak memiliki pengaruh yang signifikan adalah usia saat melahirkan anak pertama dengan nilai $p$ sebesar 0,6 dan riwayat menyusui dengan $p=0,05$.

\section{SIMPULAN}

Faktor risiko yang memiliki pengaruh terhadap ekspresi reseptor estrogen pada penderita kanker di Kota Padang yaitu paritas, status menopause, indeks massa tubuh dengan variabel yang paling dominan memberikan pengaruh adalah paritas.

Faktor risiko yang tidak memiliki pengaruh terhadap ekspresi reseptor estrogen pada penderita kanker di Kota Padang adalah usia, riwayat KPD keluarga, usia menarche, penggunaan pil KB, aktifitas fisik, usia melahirkan anak pertama dan aktifitas fisik.

\section{DAFTAR PUSTAKA}

1. Komite Nasional Penanggulangan Kanker. Pedoman nasional pelayanan kedokteran kanker payudara. Kementerian Kesehatan Republik Indonesia (diunduh 10 Desember 2017). Tersedia dari: $\quad$ http://kanker.kemkes.go.id/guidelines/PPK Payudara.pdf

2. Globocan. Breast cancer: estimated incidence, mortality and prevelance worldwide in 2012 (diunduh 2 Maret 2018). Tersedia dari: http:// globocan.iarc.fr/old/FactSheets/cancers/breastnew.asp

3. Yanti M. Faktor risiko kanker payudara pada wanita di poliklinik bedah RSUP dr. M. Djamil Padang Tahun 2016 (tesis). Padang: Fakultas Kedokteran Universitas Andalas; 2016.

4. American Cancer Society. Breast cancer facts and figures 2016 (diunduh 2 Maret 2018). Tersedia dari: http://www.cancer.org/research/cancerfacts figures/cancer-facts-figures-2013
5. Fujin C, Zhongli C, Minshan C. Buku ajar onkologi klinis. Edisi ke-2. Jakarta. Fakultas Kedokteran Universitas Indonesia; 2013.hlm.366-82.

6. Kumar V, Cotran R RS. Robbins buku ajar patologi volume 1. Edisi ke-7. Prasetyo A, Brahm U, Pendit TP, penterjemah. Jakarta: EGC; 2012.hlm.765-70.

7. Underwood JCE. Patologi umum dan sistemik. Edisi ke-2. Sarjadi, penterjemah. Jakarta: EGC; 1999.hlm. 557-60.

8. Sjamsuhidajat R, Wim DJ. Buku ajar ilmu bedah. Edisi ke-2. Jakarta: EGC; 2005.hlm.140-5.

9. Indrati R. Faktor-faktor risiko yang berpengaruh terhadap kejadian kanker payudara wanita (tesis). Semarang: Universitas Diponegoro; 2005.

10. Fatimah PAZ. Faktor risiko hormonal yang berhubungan dengan terjadinya kanker payudara di RSUP dr. M. Djamil tahun 2014 (tesis). Padang: Fakultas Kedokteran Universitas Andalas; 2014.

11. Harahap WA. Metilasi promotor gen BRCA1 dan hubungannya dengan faktor prognostik pada kanker payudara sporadik premenopausal etnis Minang (disertasi). Padang. Fakultas Kedokteran Universitas Andalas; 2013.

12. Bickley Lynn s. Bates buku ajar pemeriksaan fisik dan riwayat kesehatan. Edisi ke-8. Hartono A, penterjemah. Jakarta: EGC; 2012.hlm.303-6.

13. Putri NM. Hubungan antara usia dan body mass index (BMI) dengan fenotipe molekuler estrogen reseptor (ER) pada pasien invasive breast carcinoma of no special type (NST) di rumah sakit PKU Muhammadiyah Surakarta (tesis). Surakarta. Universitas Muhammadiyah Surakarta; 2018.

14. Choridah L. Densitas mamografi menote nilai ambang, kadar estradiol, dan polimorfisme reseptor estrogen 1 sebagai prediktor kanker payudara (disertasi). Yogyakarta. Universitas Gajah Mada; 2013.

15. Payne SJ, Bowen RL, Jones JL, Wells CA. Predictive markers in breast cancer- the present. Histopathology. 2008; 52(1):82-90.

16. Suparman E. Peran estrogen dan progesteron terhadap kanker payudara. Jurnal Biomedik (JBM). 2014;6(3):141-8. 
17. Guyton AC, Hall JE. Buku ajar fisiologi kedokteran. Edisi ke-12. Widjajakusumah M, Tanzil A, editors penterjemah. Jakarta: Saunders Elsevier. 014.hlm. 1098-9.

18. Sabiston JDC. Essential of surgery. Petrus Andrianto, penterjemah. Jakarta: EGC; 1995.hlm. 365-79.

19. Price SA, Wilson LM. Fisiologi, konsep klinis proses-proses penyakit (terjemahan). Jakarta: EGC; 1995.
20. Balasubramaniam S, Rotti S, Vivekanandam S. Risk factors of female breast carcinoma: a case control study at Puducherry. Indian $\mathrm{J}$ Cancer. 2013: 50(1):65-70.

21. Sarifudin A, Prihartono N, Guatama W. Pengaruh indeks massa tubuh terhadap disease-free survival lima tahun pasien kanker payudara di rumah sakit kanker "Dharmais". Jakarta. Indonesian Journal of Cancer. 2016:10(1):19-28. 